\title{
6 学会合同シンポジウム
}

\section{JS-6}

\section{抑制性免疫の解析によるその制御法や \\ 有効例選択バイオマーカーの探索と 変異遺伝子を標的とする複合がん免疫療法の開発}

\author{
${ }^{1}$ 山口大学医学部 先端がん治療開発学, ${ }^{2}$ 山口大学大学院 消化器・腫瘍外科学, \\ ${ }^{3}$ 山口大学大学院 免疫学, ${ }^{4}$ 近畿大学 医学部 外科学, ${ }^{5}$ 東京大学 大学院医学系研究科 細胞情報学, \\ ${ }^{6}$ 高知大学 医学部 免疫学, ${ }^{7}$ 慶應義塾大学 医学部 先端研・細胞情報
}

硲 彰一 ${ }^{1,2}$, 玉田耕治 ${ }^{3}$, 奥 野 清 隆 ${ }^{4}$, 間野博 行 $^{5}$, 宇高恵子 ${ }^{6}$, 河上 裕 ${ }^{7}$, 永野浩昭 ${ }^{2}$

近年，がん免疫療法は免疫チェックポイント阻害剤の開発で注目を集めているが効果は未だ十分とは言え ず，治療効果向上のためには，有効症例を選択する指標を確立すること，免疫チェックポイントに代表される 抑制性免疫病態を同定して制御する薬剤を同定・開発すること, 並びに腫瘍抗原由来ペプチドの同定と投与に より腫瘍抗原認識を高めることが重要である。我々は約 500 例のペプチド療法や樹状細胞療法施行症例の臨床 成績と検体（腫瘍組織・PBMC・血清）を用い, 一般臨床検查結果, サイトカイン, microRNA や蛋白の解析 から，治療前に有効症例を選択できる血液・腫瘍組織のバイオマーカーを探索・同定してきた，同時に，制御 すべき抑制性免疫について解析を行い，制御すべき負の免疫病態とそれに対応する薬剂を選択し，すでに2つ の新規複合がん免疫療法の臨床試験を平成 28 年に開始した。一方, 大腸がん原発巣と転移巣の全エクソン解 析とRNA シークエンスにより遺伝子変異を検索したが, 各患者に共通した変異は少なく, ネオアンチゲンに よる治療は個別化治療となる可能性が高い，従って HLA 高親和性ペプチドを効率よく同定する技術が必須で ありネオアンチゲン由来新規ペプチドの同定と投与により特異的免疫誘導を効率よく行うための共同研究を開 始した，以上，有効症例の選択，抑制性免疫制御，並びに個別化ネオアンチゲン由来ペプチドを用いた極めて 効果の高い複合免疫療法の開発を進める. 